\title{
PENGARUH KEPUTUSAN UTAMA TERHADAP NILAI PERUSAHAAN SEKTOR MANUFAKTUR YANG TERDAFTAR DI BEI TAHUN 2012-2016
}

\author{
Tannia $^{1)}$, Claryn Tanado ${ }^{2)}$ dan Elisa Putri ${ }^{3)}$ \\ 1) Manajemen, Universitas Bunda Mulia \\ 2) Manajemen, Universitas Bunda Mulia \\ 3) Manajemen, Universitas Bunda Mulia \\ Disetujui 19 Maret 2018
}

\begin{abstract}
The purpose of this research is to determine effect of the main decisions on firm value of manufacturing companies listed in Indonesia Stock Exchange period, of 2012-2016. The main decisions are three main functions of a financial manager in every firm. This research is a quantitative research that uses panel data and processing the panel data with E-Views. Sample of this research are 120 manufacturing companies listed in Indonesia Stock Exchange.The results that there are a significant effect of Dividend Decision on firm value and there is an insignificant effect of investment and funding decision of manufacturing companies listed in Indonesia Stock Exchange, period of 2012-2016.
\end{abstract}

Key words: Investment, Funding, Dividend, Value of Firm

\begin{abstract}
ABSTRAK
Tujuan penelitian ini adalah untuk mengetahui apakah terdapat pengaruh keputusan utama terhadap nilai perusahaan pada perusahaan sektor manufaktur yang terdaftar di Bursa Efek Indonesia tahun 2012-2016. Keputusan-keputusan utama ini merupakan tiga fungsi utama seorang manajer keuangan di setiap perusahaan. Penelitian ini merupakan penelitian kuantitatif yang menggunakan data panel dan pengolahan datanya menggunakan alat pengolah data E-Views. Sampel dalam penelitian ini sebanyak 126 perusahaan sektor manufaktur di Bursa Efek Indonesia. Hasil dari penelitian ini adalah terdapat pengaruh signifikan keputusan dividen terhadap nilai perusahaan pada perusahaan sektor manufaktur yang terdaftar di Bursa Efek Indonesia tahun 2012-2016, sedangkan tidak terdapat pengaruh signifikan keputusan investasi dan keputusan pendanaan.
\end{abstract}

Kata Kunci: Investasi, Pendanaan, Dividen, Nilai Perusahaan

\section{PENDAHULUAN}

Semua perusahaan umumnya memiliki dua tujuan yang ingin dicapai, yaitu tujuan jangka pendek dan tujuan jangka panjang (Sartini dan Purbawangsa, 2014). Tujuan jangka pendek perusahaan adalah untuk memperoleh laba secara maksimal dengan menggunakan sumber

\footnotetext{
*Korespondensi Penulis:

E-mail: tannia@bundamulia.ac.id
}

daya yang ada, sedangkan tujuan utama jangka panjang perusahaan adalah untuk memaksimalkan nilai perusahaan di mana nilai perusahaan merupakan suatu proksi yang menggambarkan kemakmuran pemegang saham (Irvaniawati dan Utiyati, 2014). Tujuan normatif dalam manajemen keuangan adalah memaksimumkan nilai perusahaan atau kemakmuran pemegang saham (Kamaludin, 2011). (1996) nilai perusahaan dapat 
mencerminkan kondisi perusahaan tersebut. Semakin tinggi harga saham, semakin tinggi nilai perusahaan, sebab nilai yang tinggi menunjukkan kemakmuran pemegang saham yang tinggi. Optimalisasi nilai perusahaan dapat dicapai melalui pelaksanaan fungsi manajemen keuangan, di mana satu keputusan keuangan yang diambil akan memengaruhi keputusan keuangan lainnya, dan berdampak pada nilai perusahaan.

Menurut Irawati (2006) fungsi utama dalam manajemen keuangan terdiri dari tiga keputusan utama yang harus dilakukan oleh suatu perusahaan, yaitu keputusan investasi, keputusan pendanaan, dan keputusan dividen.

- Pada umumnya dalam proses pengambilan keputusan investasi, investor mempertimbangkan banyak hal. Menurut Nasarudin dan Surya (2004) investor adalah orang perorangan atau lembaga baik domestik atau non-domestik yang melakukan investasi (bentuk penanaman modal sesuai dengan jenis investasi yang dipilihnya), baik dalam jangka pendek atau jangka panjang. Dalam kebijakan investasi, perusahaan diharapkan dapat memutuskan mengenai seberapa besar dana yang akan diinvestasikan dan membawa keuntungan yang tinggi dengan risiko tertentu. Berdasarkan signaling theory, pengeluaran investasi memberikan penanda positif mengenai pertambahan perusahaan di masa yang akan datang, sehingga dapat meningkatkan harga saham yang digunakan sebagai indikator nilai perusahaan (Wahyudi dan Pawestri, 2006). Pengeluaran investasi yang baik akan menguntungkan perusahaan, sehingga dapat menyejahterakan para investor maupun pemegang saham.

- Keputusan yang kedua adalah keputusan pendanaan. Keputusan pendanaan membantu perusahaan mengalokasikan, mempertimbangkan dan menganalisis pendanaan perusahaan, maupun sumber investasi perusahaan. Perusahaan membutuhkan keputusan pendanaan yang baik untuk mempertimbangkan jumlah dana yang digunakan perusahaan untuk melakukan kegiatan operasional atau cara perusahaan membiayai aktivanya serta mencapai tingkat laba perusahaan yang maksimal.

- Selain keputusan investasi dan keputusan pendanaan, perusahaan juga perlu memperhatikan keputusan dividen. Dividen merupakan keuntungan yang didapat para pemegang saham atas investasi yang telah dilakukan. Jumlah dividen yang dibayarkan akan menentukan tingkat kesejahteraan para pemegang saham. Perusahaan mengharapkan pertumbuhan yang stabil, sehingga dapat mempertahankan kelangsungan hidup perusahaannya dan dapat memberikan kesejahteraan kepada para pemegang sahamnya, sehingga keputusan dividen penting untuk memenuhi harapan pemegang saham terhadap dividen dengan tidak menghambat pertumbuhan perusahaan di sisi lainnya.

Dalam proses pelaksanaan keputusan investasi, keputusan pendanaan dan keputusan dividen harus dilakukan dengan cermat dan hati-hati, karena setiap keputusan yang diambil akan memengaruhi pencapaian tujuan dan nilai perusahaan.

Agar tujuan perusahaan untuk memaksimalkan kekayaan pemegang saham dapat tercapai, maka perlu diambil berbagai keputusan keuangan (financial decision) yang relevan dan mempunyai pengaruh bagi peningkatan nilai perusahaan (Moeljadi, 2006).

\section{TINJAUAN PUSTAKA}

\section{Fungsi Manajemen Keuangan}

Menurut Sutrisno (2012) fungsi manajemen keuangan terdiri dari tiga keputusan utama yang harus dilakukan oleh suatu perusahaan yaitu keputusan investasi, 
keputusan pendanaan dan keputusan dividen.

Keputusan investasi adalah masalah bagaimana manajer keuangan harus mengalokasikan dana ke dalam bentukbentuk investasi yang akan dapat mendatangkan keuntungan di masa yang akan datang. Bentuk, macam dan komposisi dari investasi tersebut akan memengaruhi dan menunjang keuntungan di masa depan.

Keputusan pendanaan sering disebut sebagai keputusan struktur modal. Pada keputusan ini manajemen keuangan dituntut untuk mempertimbangkan dan menganalisis kombinasi dari sumbersumber dana yang ekonomis bagi perusahaan guna membelanjai kebutuhankebutuhan investasi serta kegiatan usahanya.

Keputusan dividen merupakan keputusan manajemen keuangan untuk menentukan besarnya persentasi laba yang dibagikan kepada para pemegang saham dalam bentuk dividen tunai, stabilitas dividen yang dibagikan, dividen saham, pemecahan saham, dan penarikan kembali saham yang beredar. Semua ketentuan keputusan ini ditujukan untuk meningkatkan kemakmuran para pemegang saham.

\section{Pengaruh antar Peubah}

Pengaruh Keputusan Investasi terhadap Nilai Perusahaan

Menurut Wahyudi dan Pawestri (2006), nilai perusahaan yang dibentuk melalui indikator nilai pasar saham sangat dipengaruhi oleh Pengeluaran investasi yang dikeluarkan akan memberikan pengaruh terhadap pertumbuhan perusahaan untuk masa yang akan datang. Pertumbuhan perusahaan adalah faktor yang penting, mengingat investor mengharapkan pengembalian yang menguntungkan dari perusahaan.

$\begin{array}{lcr}\text { Wijaya dan } & \text { Wibawa } & (2010) \\ \text { memberikan hasil penelitian } & \text { yang } \\ \text { menunjukkan sifat signifikan antara } & \text { an } \\ \text { keputusan investasi terhadap nilai } \\ \text { perusahaan. Keputusan untuk berinvestasi } \\ \text { harus dipertimbangkan dengan cermat }\end{array}$

karena akan berpengaruh terhadap penambahan atau pengurangan nilai perusahaan.

H1: Terdapat pengaruh Keputusan Investasi terhadap Nilai Perusahaan.

\section{Pengaruh Keputusan Pendanaan terhadap Nilai Perusahaan}

Keputusan pendanaan merupakan hal yang sangat penting karena keputusan pendanaan menentukan struktur modal yang digunakan, apakah didominasi oleh hutang maupun didominasi oleh dana investor. Keterhubungan keputusan pendanaan dengan nilai perusahaan sering kali tidak terlihat namun, Jensen (1976), menyatakan bahwa dengan adanya utang, maka dapat digunakan untuk mengendalikan arus uang tunai bebas secara berlebihan oleh manajemen, dengan demikian menghindari investasi yang siasia dan akan meningkatkan nilai perusahaan.

Peningkatan rasio utang suatu perusahaan merupakan penanda positif bagi investor dengan asumsi bahwa arus uang tunai perusahaan di masa mendatang akan terjaga dan adanya utang juga menunjukkan optimisme dari manajemen dalam melakukan investasi. Diharapkan bahwa di masa mendatang prospek perusahaan semakin cerah.

H2: Terdapat pengaruh Keputusan Pendanaan terhadap Nilai Perusahaan.

\section{Pengaruh Keputusan Dividen terhadap Nilai Perusahaan}

Rasio ini memperlihatkan proporsi antara kewajiban yang dimiliki dan seluruh kekayaan yang dimiliki. Semakin tinggi hasil persentasinya cenderung semakin. besar risiko keuangannya bagi kreditor maupun pemegang saham (Suroto, 2015).

Prasetyo (2011) menyatakan manajer yang berhasil menciptakan keputusan investasi yang tepat, maka aset yang diinvestasikan akan menghasilkan kinerja yang optimal, sehingga memberikan suatu penanda positif kepada investor yang nantinya akan meningkatkan harga saham dan nilai perusahaan. 


\section{H3: Terdapat pengaruh Keputusan Dividen terhadap Nilai Perusahaan.}

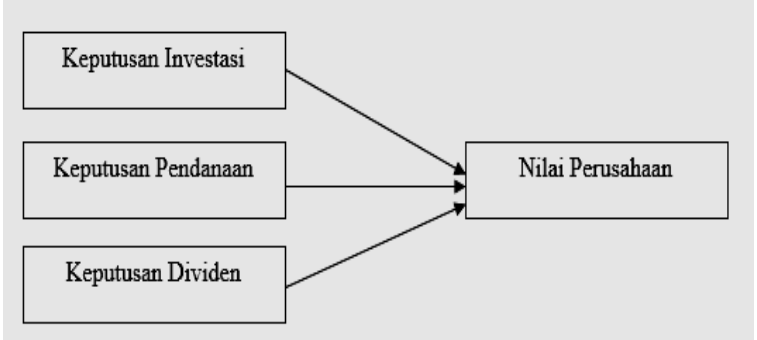

Gambar 1. Model Penelitian

Sumber: Diolah peneliti (2017)

\section{METODE PENELITIAN}

Penelitian ini merupakan penelitian kuantitatif kausal atau disebut juga ex-post facto. Menurut Sedarmayanti dan Hidayat (2011, p33) penelitian ex-post facto adalah penelitian yang dilakukan untuk meneliti penyebab atau pengaruh atas peristiwa atau kondisi nilai perusahaan yang telah terjadi dengan menggunakan data yang telah ada atau data sekunder.

Dalam penelitian ini pengambilan sampel dilakukan dengan teknik purposive sampling yaitu teknik pengambilan sampel yang dilakukan berdasarkan pertimbangan yang memumpun pada tujuan tertentu. Berikut kriteria sampel yang ditentukan oleh peneliti:

1. Perusahaan bergerak di sektor manufaktur.

2. Perusahaan telah mencatatkan dirinya di Bursa Efek Indonesia.

3. Perusahaan berdiri dan beroperasi selama tahun 2012-2016.

4. Tidak delisted / suspended selama tahun 2012-2016.

5. Perusahaan memiliki ketersediaan dan kelengkapan data yang dibutuhkan dalam penelitian.

Jumlah seluruh perusahaan manufaktur tercatat pada tahun 2016 adalah sebanyak 155 perusahaan. Namun terdapat perusahaan yang baru melakukan IPO di tengah tahun penelitian ini yaitu tahun 2013 (5 perusahaan), 2014 (5 perusahaan), dan 2015 (8 perusahaan) dengan total sebanyak
18 perusahaan. Selain itu, juga terdapat perusahaan yang mengalami delisted/suspended di tengah tahun penelitian ini, yaitu tahun 2013 (3 perusahaan), 2014 (2 perusahaan), dan 2015 (6 perusahaan) dengan total sebanyak 11 perusahaan. Berdasarkan hal ini, maka perusahaan tersebut dikeluarkan dari sampel penelitian sehingga jumlah keseluruhan perusahaan manufaktur pada periode 2012-2016 adalah sebanyak 126 perusahaan. Namun terdapat 5 perusahaan sampel yang tidak memiliki ketersediaan data, sehingga dihapus dari sampel penelitian ini. Oleh karena itu, jumlah sampel akhir dalam penelitian ini adalah sebanyak 121 perusahaan sektor manufaktur.

Penelitian ini menggunakan teknik analisis regresi data panel. Regresi data panel merupakan kombinasi antara data silang (cross section) dan data runtut waktu (time series), di mana unit cross section yang sama diukur pada waktu yang berbeda. Pengujian regresi data panel dilakukan dengan menggunakan alat pengolah data yaitu software Eviews.

Menurut Widarjono (2007) model estimasi data panel dapat dilakukan melalui 3 pendekatan yaitu Common Effect Model (Pooled Least Square), Fixed Effect Model, dan Random Effect Model.

Common Effect Model atau Pooled Least Square merupakan pendekatan model data panel yang mengombinasikan data time series dan cross section. Model ini merupakan model paling sederhana. Pada 
model ini tidak diperhatikan dimensi waktu maupun individu, sehingga diasumsikan bahwa perilaku data perusahaan sama dalam berbagai kurun waktu.

Fixed Effect Model merupakan pendekatan model dengan mengasumsikan bahwa perbedaan antar individu dapat diakomodasi dari perbedaan intersepnya, sedangkan kemiringan antar individu tetap sama. Teknik ini menggunakan peubah kualitatif agar menjadi kuantitatif untuk menangkap perbedaan intersep antar individu.

Random Effect Model merupakan pendekatan model dengan mengestimasi data panel di mana peubah gangguan mungkin saling berhubungan antar waktu dan antar individu. Pada model Random Effect perbedaan intersep diakomodasi oleh error terms masing-masing perusahaan. Keuntungan menggunakan model Random Effect yaitu menghilangkan heteroskedastisitas.

\section{Pengukuran Peubah \\ Peubah Gayut}

Peubah gayut adalah peubah yang dipengaruhi oleh variabel lain. Variabel dependen yang digunakan adalah nilai perusahaan.

\section{Nilai Perusahaan}

Dalam penelitian ini, peubah untuk Nilai Perusahaan memiliki pengukur yaitu Price to Book Value.

Husnan (2001) secara fundamental rasio ini diperhatikan oleh investor dalam memilih saham karena perusahaan yang mempunyai nilai PER yang tinggi menunjukkan nilai pasar yang tinggi pula atas saham tersebut, sehingga saham tersebut akan diminati oleh investor. Hal ini pada akhirnya akan berdampak pada kenaikan harga saham. Sebaliknya apabila perusahaan mempunyai PER yang rendah menunjukkan nilai pasar yang rendah sehingga akan berdampak terhadap penurunan harga saham.

$$
\text { PER }=\frac{\text { Stock } \text { Price }}{\text { EPS }}
$$

$\mathrm{PER}=$ Price Earning Ratio

Stock Price $=$ Harga per lembar saham

EPS= Earning Per Share

\section{Peubah Bebas}

Peubah bebas adalah peubah yang menjelaskan atau memengaruhi peubah lain. Peubah bebas dalam penelitian ini adalah keputusan investasi, keputusan pendanaan, dan keputusan dividen.

\section{Keputusan Investasi}

Dalam penelitian ini, peubah Keputusan Investasi memiliki pengukur yaitu Capital Expenditure to Book Value. Horngren et al (2006) menyatakan "Pengeluaran Modal (Capital Expenditure) adalah pengeluaran yang meningkatkan kapasitas atau efisiensi aktiva atau yang memperpanjang masa manfaat. Formula CAP/BVA (Capital Expenditure to Book Value of Asset) dalam penelitian Mardiyati et al (2015) adalah:

$$
C P A / B V A=\frac{\text { Pertumbuhan Aktiva }}{\text { Total Aktiva }}
$$

$\mathrm{CPA} / \mathrm{BVA}=$ Ratio Capital Expenditure to Book Value of Asset

Pertumbuhan Aktiva $=$ Aktiva Total Tahun $\mathrm{X}$ - Aktiva Total Tahun X-1

\section{Keputusan Pendanaan}

Dalam penelitian ini, variabel Kebijakan Pendanaan memiliki dua pengukur yaitu Debt to Asset Ratio.

Menurut Agnes Sawir (2000) ada dua jenis rasio leverage yaitu rasio utang terhadap aset dan rasio utang terhadap modal.

Rasio ini memperlihatkan proporsi antara kewajiban yang dimiliki dan seluruh kekayaan yang dimiliki. Semakin tinggi hasil persentasinya, cenderung semakin besar risiko keuangannya bagi kreditor maupun pemegang saham. 
DAR $=\frac{\text { Total Hutang }}{\text { Total Aktiva }} \times 100 \%$

$\mathrm{DAR}=$ Debt to Asset Ratio

\section{Keputusan Dividen}

Dalam penelitian ini, variabel keputusan dividen memiliki pengukur yaitu Earning Per Share.

Menurut Fahmi (2012), EPS atau pendapatan per lembar saham adalah bentuk pemberian keuntungan yang diberikan kepada para pemegang saham dari setiap lembar saham yang dimiliki. Rumus untuk menghitung EPS suatu perusahaan adalah sebagai berikut:

EPS $=$

Net income-Preferred Dividends

Average Number of Common Share Outstanding

EPS $=$ Earnings Per Share

Net Income = laba bersih setelah pajak

Preferred dividend $=$ dividen saham preferen

Average Number of common share outstanding $=$ rata - rata jumlah saham yang beredar

\section{HASIL DAN PEMBAHASAN}

\section{Chow Test}

Pengujian Chow Test dilakukan untuk menentukan model Common Effect atau Fixed Effect yang lebih tepat digunakan. Hasil hipotesis yang dibentuk dalam Chow Test adalah sebagai berikut:

1. Apabila nilai probabilitas lebih besar dari tingkat signifikan yang sudah ditentukan (> 0.05), maka data tersebut adalah Common Effect Model.

2. Apabila nilai probabilitas lebih kecil dari tingkat signifikan yang sudah ditentukan $(<0.05)$, maka data tersebut adalah Fixed Effect Model. Jika hasil hipotesis adalah Fixed Effect Model, selanjutkan dilakukan pengujian dengan Housman Test.

Tabel 1. Chow Test

\begin{tabular}{|c|c|c|c|}
\hline Effects Test & Statistic & d.f. & Prob. \\
\hline Cross-section F & 6.968379 & $(118,473)$ & 0.0000 \\
\hline Cross-section Chi-square & 599.389977 & 118 & 0.0000 \\
\hline
\end{tabular}

Sumber: Hasil olah data oleh peneliti (2017)

Hasil uji data Chow Test, memperlihatkan nilai probabilitas sebesar 0,00 pada Cross-section Chi-Square. Hal ini menunjukkan bahwa nilai probabilitas lebih kecil dari 0,05, maka data sampel merupakan Fixed Effect Model. Namun, karena data merupakan Fixed Effect Model, peneliti melanjutkan pengujian hipotesis dengan uji Housman.

\section{Housman Test}

Pengujian Housman Test dilakukan untuk pengujian statistik dalam memilih dan menentukan Fixed Effect Model atau Random Effect Model yang lebih tepat digunakan. Hasil hipotesis yang dibentuk dalam Housman Test adalah sebagai berikut:

1. Apabila nilai probabilitas lebih besar dari tingkat signifikan yang sudah ditentukan (> 0.05), maka data tersebut adalah Random Effect Model. 
2. Apabila nilai probabilitas lebih kecil dari tingkat signifikan yang sudah ditentukan $(<0.05)$, maka data tersebut adalah Fixed Effect Model. Jika hasil hipotesis adalah Fixed Effect Model, selanjutnya akan dilakukan Lagrange Multiplier Test

Tabel 2. Housman Test

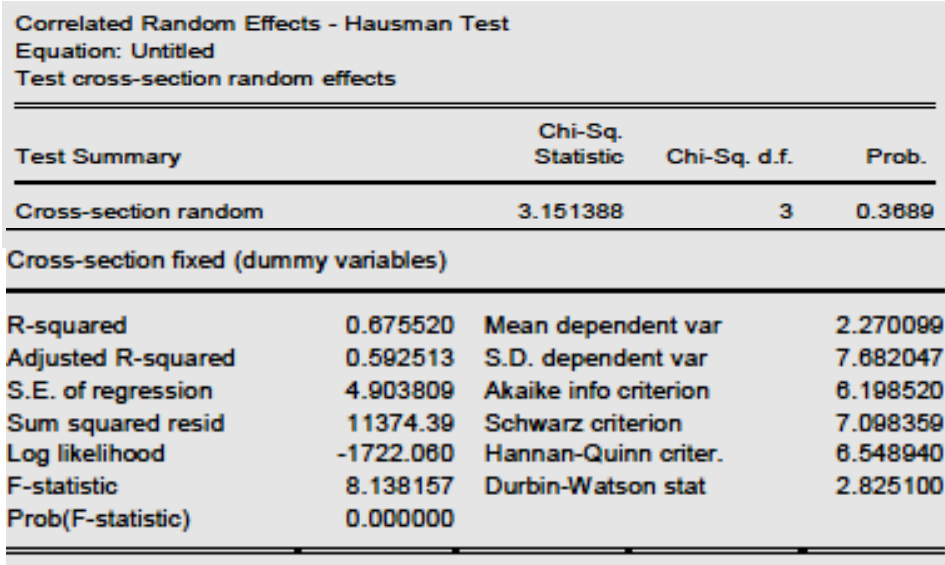

Sumber: Hasil olah data oleh peneliti (2017)

Hasil uji Housman Test, memperlihatkan nilai probabilitas sebesar 0,3689 pada Cross-section Random, hal ini menunjukkan bahwa nilai probabilitas lebih besar dari 0,05 maka data sampel merupakan Random Effect Model. Nilai $R$ Square sebesar 0,6755 dan lebih besar dari 0,5 yang menunjukkan kemampuan peubah bebas kuat dalam menjelaskan keterbatasan peubah gayut. Maka tidak perlu melakukan pengujian dengan Lagrange Multiplier Test.

\section{Uji Koefisien Determinasi}

Menurut Ghozali (2013) koefisien determinasi mengukur kemampuan model dalam menerangkan keterubahan peubah. Koefisien determinasi dinotasikan dengan $\mathrm{R} 2$ atau R Squares. Penentuan hasil uji koefisien determinasi adalah sebagai berikut:

1. Apabila nilai R2 menjauhi angka satu, artinya peubah bebas tidak dapat banyak memberikan informasi untuk menjelaskan keterubahan peubah gayut.

2. Apabila nilai R2 mendekati angka satu, artinya peubah bebas dapat banyak memberikan informasi untuk menjelaskan keterubahan prubah gayut.
Berdasarkan Tabel 3. Housman Test, hasil uji koefisien determinasi, menunjukkan bahwa nilai $\mathrm{R}$ Squares sebesar 0.675520, artinya sebesar $67.5520 \%$ keterubahan dari peubah gayut dalam penelitian ini yaitu Nilai Perusahaan dapat dijelaskan oleh perubah bebas yaitu Keputusan Investasi, Keputusan Pendanaan, dan Keputusan Dividen. Sisanya sebesar $32.448 \%$ dijelaskan oleh peubah atau faktor lain di luar penelitian ini.

\section{Uji F}

Uji $F$ berguna untuk menunjukkan bahwa semua peubah bebas dalam model memiliki pengaruh yang simultan terhadap peubah gayut (Ghozali, 2013). Penentuan hasil uji $\mathrm{F}$ adalah sebagai berikut:

1. Apabila nilai probabilitas di bawah 0.05 $(<0.05)$, artinya peubah bebas secara simultan berpengaruh terhadap peubah gayut.

2. Apabila nilai probabilitas di atas 0.05 artinya (>0.05), artinya peubah bebas secara simultan tidak berpengaruh terhadap peubah gayut 
Tabel 3. Uji F

\begin{tabular}{lrll}
\hline Cross-section fixed (dummy variables) & & \\
\hline R-squared & 0.675520 & Mean dependent var & 2.270099 \\
Adjusted R-squared & 0.592513 & S.D. dependent var & 7.682047 \\
S.E. of regression & 4.903809 & Akaike info criterion & 6.198520 \\
Sum squared resid & 11374.39 & Schwarz criterion & 7.098359 \\
Log likelihood & -1722.060 & Hannan-Quinn criter. & 6.548940 \\
F-statistic & 8.138157 & Durbin-Watson stat & 2.825100 \\
Prob(F-statistic) & 0.000000 & & \\
\hline \hline
\end{tabular}

Sumber: Hasil olah data oleh peneliti (2017)

Hasil uji $\mathrm{F}$ menunjukkan bahwa nilai Prob (F-statistic) sebesar 0.000000 lebih kecil dari 0.05, sehingga dapat disimpulkan bahwa peubah bebas secara simultan berpengaruh terhadap peubah gayut atau bahwa paling tidak ada salah satu peubah bebas (CAPEX, DAR, atau EPS) yang berpengaruh signifikan terhadap nilai perusahaan pada perusahaan sektor manufaktur yang terdaftar di Bursa Efek Indonesia tahun 2012-2016.

\section{Uji T}

Menurut Ghozali (2013) uji statistik $\mathrm{T}$ digunakan untuk menunjukkan besarnya pengaruh satu peubah bebas terhadap peubah gayut dengan menganggap peubah bebas lainnya konstan. Penentuan hasil uji $\mathrm{T}$ adalah sebagai berikut:

1. Apabila nilai probabilitas di bawah 0.05 (< 0.05), artinya pengaruh peubah bebas signifikan terhadap peubah gayut.

2. Apabila nilai probabilitas di atas 0.05 (> 0.05), artinya pengaruh peubah bebas tidak signifikan terhadap peubah gayut.

\section{Pengaruh Keputusan}

\section{Tabel 4. Uji T}

\begin{tabular}{|c|c|c|c|c|}
\hline Variable & Coefficient & Std. Error & t-Statistic & Prob. \\
\hline $\mathrm{c}$ & 1.977372 & 0.308734 & 6.404770 & 0.0000 \\
\hline CAPEX & 0.000826 & 0.003843 & 0.214969 & 0.8299 \\
\hline DAR & -0.027110 & 0.395900 & -0.068477 & 0.9454 \\
\hline EPS & 0.000463 & $6.12 \mathrm{E}-05$ & 7.563031 & 0.0000 \\
\hline
\end{tabular}

Sumber: Hasil olah data oleh peneliti (2017)

Uji $\mathrm{T}$ menunjukkan nilai Prob CAPEX yang mengukur Keputusan Investasi sebesar 0.8299 lebih besar dari 0.05 , sehingga dapat disimpulkan bahwa Keputusan Investasi tidak berpengaruh signifikan terhadap Nilai Perusahaan pada perusahaan sektor manufaktur yang terdaftar di Bursa Efek Indonesia tahun 2012-2016.

Berdasarkan uji T nilai Prob DAR yang mengukur Keputusan Pendanaan sebesar 0.9454 lebih besar dari 0.05 , 
sehingga dapat disimpulkan bahwa Keputusan Pendanaan tidak berpengaruh signifikan terhadap Nilai Perusahaan pada perusahaan sektor manufaktur yang terdaftar di Bursa Efek Indonesia tahun 2012-2016.

Berdasarkan uji T nilai Prob EPS yang mengukur Keputusan Dividen sebesar 0.0000 lebih kecil dari 0.05, sehingga dapat disimpulkan bahwa Keputusan Dividen berpengaruh signifikan terhadap Nilai Perusahaan pada perusahaan sektor manufaktur yang terdaftar di Bursa Efek Indonesia tahun 2012-2016.

\section{SIMPULAN DAN SARAN}

\section{Simpulan}

Berdasarkan hasil yang diperoleh dari penelitian ini, peneliti menyimpulkan bahwa keputusan investasi tidak berpengaruh terhadap nilai suatu perusahaan khususnya perusahaan sektor manufaktur. Pada dasarnya keputusan investasi perlu dipikirkan dengan cermat untuk menentukan keberlangsungan hidup perusahaan, khususnya dari sisi bagaimana perusahaan tersebut dapat menghasilkan laba dari investasi. Apabila perusahaan dapat dengan tepat menentukan keputusan investasi, dapat berdampak pada nilai perusahaan yang baik. Namun penelitian ini menghasilkan bahwa keputusan investasi perusahaan belum tentu berdampak pada nilai perusahaan.

Hasil ini sesuai dengan keadaan di pasar modal khususnya pada pasar investasi saham. Seorang investor, khususnya investor Indonesia cenderung tidak melihat perusahaan mengalokasikan dana untuk investasi dalam sarana investasi apa dan seberapa besar.

Dalam penelitian ini disimpulkan bahwa keputusan pendanaan tidak berpengaruh terhadap nilai suatu perusahaan khususnya perusahaan sektor manufaktur. Pada dasarnya keputusan pendanaan khususnya pada perusahaan manufaktur perlu dipikirkan dengan sangat matang. Hal ini dikarenakan pada umumnya jumlah pendanaan perusahaan manufaktur cenderung tidak sedikit, sehingga harus dipikirkan dengan baik untuk menentukan keberlangsungan hidup perusahaan, khususnya dari sisi bagaimana perusahaan tersebut dapat memperoleh sumber dana dan bagaimana perusahaan tersebut melunasi bunga dan pokok pinjamannya kelak. Apabila perusahaan dapat dengan cermat menentukan keputusan pendanaan, dapat berdampak pada nilai perusahaan yang baik. Namun penelitian ini menunjukkan bahwa keputusan pendanaan perusahaan belum tentu berdampak pada nilai perusahaan.

Hasil ini sesuai dengan keadaan di pasar modal, khususnya pada pasar investasi saham. Seorang investor, khususnya investor Indonesia cenderung tidak melihat perusahaan memperoleh dananya dari mana dan seberapa besar penggunaan sumber dana eksternal yang dilakukan perusahaan.

Dalam penelitian ini disimpulkan bahwa keputusan dividen berpengaruh signifikan terhadap nilai perusahaan khususnya perusahaan sektor manufaktur. Pada dasarnya keputusan dividen bukan merupakan suatu kewajiban yang harus dilakukan oleh setiap perusahaan terbuka. Keputusan untuk memberikan dividen diserahkan seluruhnya pada perusahaan, tidak ada pihak yang berhak menuntut dividen suatu perusahaan. Namun, walaupun dividen bukanlah hal yang pasti bahkan rutin, keputusan dividen yang dilakukan perusahaan tetap memberikan dampak terhadap nilai perusahaan. Hal ini sesuai dengan hasil penelitian ini.

Keputusan dividen yang berpengaruh signifikan terhadap nilai perusahaan juga sesuai dengan keadaan di pasar modal, khususnya pada pasar investasi saham. Seorang investor, khususnya investor Indonesia cenderung melihat perusahaan yang memberikan dividen sebagai perusahaan yang memiliki nilai lebih ketimbang dengan perusahaan lain. Hal ini dikarenakan tujuan utama dari seorang investor, khususnya investor saham adalah untuk memperoleh keuntungan. 
Terdapat 2 (dua) bentuk keuntungan dalam investasi saham. Keuntungan yang pertama adalah dari capital gain, yaitu selisih harga beli dan harga jual di mana harga jual lebih tinggi. Keuntungan yang kedua adalah dari dividen itu sendiri. Oleh karena itu, dividen merupakan hal yang dapat menambah nilai suatu perusahaan terutama bagi seorang investor.

\section{Keterbatasan Peneliti}

Adapun keterbatasan dari penelitian ini adalah:

1. Penelitian hanya menggunakan sampel dari sektor manufaktur, sehingga kurang mewakili seluruh sektor industri yang terdaftar di Bursa Efek Indonesia.

2. Penelitian hanya menguji tiga faktor yang memengaruhi nilai perusahaan, yaitu keputusan investasi, keputusan pendanaan, dan keputusan dividen.

3. Penelitian hanya mengambil periode selama lima tahun yaitu 2012-2016 sehingga data kemungkinan kurang mencerminkan kondisi perusahaan dalam jangka panjang.

\section{Saran}

Berdasarkan simpulan yang diperoleh dalam penelitian ini, maka berikut adalah saran dari hasil penelitian ini:

1. Perusahaan terbuka tidak perlu khawatir apabila belum dapat menentukan sarana investasi yang tepat bagi perusahaan. Namun sebagai salah satu tugas utama seorang manajer keuangan, hal ini tetap menjadi prioritas dengan memumpun pada keberlangsungan hidup perusahaan khususnya pada pencapaian keuntungan di masa yang akan datang. Perusahaan yang ingin meningkatkan nilainya, sebaiknya dapat lebih mempertimbangkan pengalokasian laba yang diperoleh untuk digunakan sebagai bentuk pemberian dividen bagi pemegang saham.

2. Perusahaan terbuka tidak perlu khawatir apabila akan melakukan peningkatan pendanaan seperti pinjaman. Namun sebagai salah satu tugas utama seorang manajer keuangan, hal ini tetap menjadi prioritas dengan memumpun pada penggunaan dana tersebut dan pelunasan pinjaman, baik dalam pembayaran bunga maupun dalam pembayaran pokok pinjaman di waktu jatuh tempo sesuai perjanjian yang sudah dibuat. Perusahaan yang ingin meningkatkan nilainya, sebaiknya dapat lebih mempertimbangkan pengalokasian laba yang diperoleh untuk digunakan sebagai bentuk pemberian dividen bagi pemegang saham.

3. Perusahaan terbuka untuk lebih bijak dalam hal penggunaan laba perusahaan. Pada umumnya, perusahaan dapat mengalokasikan laba yang diperoleh untuk dijadikan sebagai laba ditahan maupun sebagai dividen. Apabila perusahaan memiliki satu rencana pengeluaran besar (misalnya ekspansi) perusahaan memang dapat memutuskan untuk tidak membagikan dividen. Namun berdasarkan hasil penelitian ini, keputusan dividen dapat memengaruhi nilai perusahaan secara signifikan. Oleh karena itu, perusahaan terbuka yang sudah menerbitkan saham, sebaiknya dapat memumpun untuk membagikan dividen sebagai bentuk peningkatan nilai perusahaannya. Hal ini juga sesuai dengan salah satu tugas utama seorang manajer keuangan, yaitu meningkatkan kesejahteraan para pemegang saham.

\section{Agenda Keberlanjutan}

Berdasarkan kesimpulan dan saran dari penelitian ini, berikut adalah agenda penelitian berikutnya:

1. Memperluas hasil penelitian dengan mengkaji dan membandingkan satu sektor dengan sektor lainnya sehingga dapat mengetahui apakah sektor lain memiliki pengaruh dalam penelitian ini.

2. Memperluas hasil penelitian dengan meneliti seluruh perusahaan dan tidak memisahkannya ke dalam sektor-sektor tertentu sehingga mendapat kesimpulan yang lebih umum. 
3. Mengembangkan penelitian dengan meneliti unsur behavioral finance of investor yang ada pada investor saham.

4. Pada penelitian lanjutan dapat dilakukan dengan menggunakan data periode diatas 5 tahun dengan data yang terbaru sehingga hasil dapat menunjukkan situasi/kondisi pasar yang baru.

5. Pada penelitian lanjutan perlu ditambahkan peubah-peubah lain yang berkaitan dengan nilai perusahaan.

\section{DAFTAR PUSTAKA}

Sawir, Agnes. (2009). Analisa Kinerja Keuangan dan Perencanaan Keuangan Perusahaan. Jakarta: PT. Gramedia Pustaka Utama.

E.F., Brigham, dan Louis C, Gapenski. (1996). Intermadiate Finance Management. 5th ed. Harbor Drive: The Dryden Press.

Fahmi, Irham. (2012). Pengantar Manajemen Keuangan: Teori dan Soal Jawab. Bandung: Alfabeta.

Ghozali, Imam, dan Dwi Ratmono. (2013). Analisis Multivariat dan Ekonometrika: Teori, Konsep dan Aplikasi dengan Eviews 8. Semarang: Universitas Diponegoro. Horngren, Charles T., Srikant M. Datar, dan George Foster. (2006). Cost Accounting: A Managerial Emphasis. 12th edition. New Jersey: Pearson Prentice Hall.

Irawati, Susan. (2006). Manajemen Keuangan. Bandung: PT Pustaka.

Irvaniawati dan Utiyati, Sri. (2014). "Analisis Pengaruh Kebijakan Hutang, Kebijakan Investasi, dan Kebijakan Deviden terhadap Nilai Perusahaan". Jurnal Ilmu \& Riset Manajemen. Vol. 3, No. 6, 2014.

Jensen, Michael C.,dan Meckling, William H. (1976). "Theory Of The Firm: Manajerial Behavior, Agency Cost And Ownership Structure". Journal of Financial Economics, 3, pp: 305-360.
Mardiyati, Umi., Nazir, Gatot, A., dan Abrar, M. (2015). "Pengaruh Keputusan Investasi, Keputusan Pendanaan, Ukuran Perusahaan dan Profitabilitass terhadap Nilai Perusahaan pada Sektor Manufaktur Barang Konsumsi yang terdaftar di Bursa Efek Indonesia periode 20102013". Jurnal Riset Manajemen Sains Indonesia. Vol. 6, No. 1, 2015.

Moeljadi. (2006). Manajemen Keuangan 1: Pendekatan Kuantitatif dan Kualitatif. Edisi Pertama. Malang: Bayumedia Publishing.

Nasarudin, M.Irsan, dan Surya Indra. (2004). Aspek-Aspek Hukum Pasar Modal Indonesia. Jakarta: Prenada Media.

Prasetyo, Aries Heru. (2011). Valuasi Perusahaan. Jakarta : PPM.

Sartini, Luh Putu Novita dan Purbawangsa, Ida Bagus Anom. (2014). "Pengaruh Keputusan Investasi, Kebijakan Dividen, serta Keputusan Pendanaan terhadap Nilai Perusahaan Manufaktur di Bursa Efek Indonesia”. Jurnal Manajemen, Strategi Bisnis dan Kewirausahaan. Vol. 8, No. 2, Agustus 2014.

Sedarmayanti dan Hidayat, Syarifudin. (2011). Metodologi Penelitian. Bandung: Mandar Maju.

Sutrisno. (2012). Manajemen Keuangan Teori, Konsep dan Aplikasi. Edisi 8. Yogyakarta: Ekonisia.

Suroto. (2015). "Pengaruh Keputusan Investasi, Keputusan Pendanaan dan Kebijakan Dividen Terhadap Nilai Perusahaan (Studi Empiris Pada Perusahaan Lq-45 Yang Terdaftar Di

Bursa Efek Indonesia Periode Februari 2010-Januari 2015)". Jurnal Ilmiah UNTAG Semarang. Vol. 4 No. 3, 2015. 
Wahyudi, U. dan H.P. Pawestri. (2006). "Implikasi Struktur Kepemilikan terhadap Nilai Perusahaan dengan Keputusan Keuangan sebagai Peubah Intervening". Simposium Nasional Akuntansi 9. Padang.
Wijaya, Lihan Rini Puspo dan Anas Wibawa. (2010). "Pengaruh Keputusan Investasi, Keputusan Pendanaan dan Kebijakan Dividen Terhadap Nilai Perusahaan". Simposium Nasional Akuntansi 13. 